\title{
The Readability of Reading Text on The English Textbook for XI Grade Students Published by The Ministry of Educational and Cultural Indonesia 2019
}

\author{
Rr Ajutriesna Lawijanti Indryasari \\ STKIP PGRI Sidoarjo, Email: nenengprang@gmail.com
}

\begin{abstract}
This research sought to explore the readability of textbook for use by Senior High School Grade XI Semester 1 student in the year 2019. This research is used descriptive qualitative. It means that reading is about understanding written texts. If reading English text is not interest, vocabularies are hard to understand, the students get difficult to understand the reading passage. The readability level of text is needed to motivate students to be able to build up their interest in reading text. This research investigates the readability level of reading texts in English Textbook Entitled "Bahasa Inggris" for senior high school students grade XI. The method used in this study is descriptive qualitative. The data were gathered through analysis the readability level of the texts used Flesch Reading Ease Formula.
\end{abstract}

Keywords: English text book, Readability level, textbook.

\section{INTRODUCTION}

Textbook is a kind of teaching and learning media that most commonly used in every teaching and learning process although many innovative media have been developed to help the educators or teachers to teach in new ways. It is kind of printed materials that have an important part in teaching and learning process.

In learning a language, it is important to make sure that the reading material is a readable for learners. The readable material is less material to be considered by the teachers as long as to improve students' ability in understanding the materials. The English textbook used in understanding the material easily and better.

There is main purpose of the study. They are to investigate the formulated readability towards students' comprehension results on factual report texts of eleventh graders senior high school in Surabaya. To find out the English teacher and students of eleventh grader response towards reports text as students' reading materials of eleventh graders.

The subject of this study is two reading texts in English textbook entitled "BAHASA INGGRIS SMA/MA/MAK FOR GRADE XI" that published by The 
Ministry of Education and Culture of Indonesia in 2018/2019 under Kurikulum 2013. This book has used by the $11^{\text {th }}$ grade students of Senior High School in Surabaya, one of chosen school by the government implemented the book. This book is analyzed because of some reasons.

The purpose is to find out whether the readability of the eleventh graders students' reading passages in the textbook that officially made by Indonesian government which have been conducted before is match with the factual condition in the classroom application which is with provide with students' achievement.

Readability in this research is defined by measuring the reading text level in English textbook entitled "Bahasa Inggris" for senior high school grade XI. Readability formula is the easiest formula to read only explains a number of factors, especially sentences, word lengths and syllables, since these factors best indicate ease of reading.

\section{METHOD}

This researcher is used descriptive qualitative. The purpose of descriptive research is to become more familiar with phenomena, to gain new insight, and to formulate a more specific research problem or hypothesis. It means that reading is about understanding written texts. Research can be described as a systematic and organized effort to investigate a specific problem to provide a solution (Sekaran; 2000; Burn, 1994). Research can be classified into three basic categories: quantitative, qualitative and mixed methods research (Creswell, 2008; Cohen et al., 2007; Gliner et al., 2009; Kothari, 2010. In contrast, experimental research is to test cause and affect relationships among variables. Meanwhile, Creswell (2003) said that the decision of what method a researcher employs depends they are the research problem, the researcher's experience, the reporting audience are Exploratory research, just as the word implies, it explores, that is to find out about something by answering the question in what or how manner, descriptive research, this is more in-depth research, that answered the question what and how. The researcher use research design of this study is descriptive qualitative since the research only reveal the exiting data resulted by analyzing the content of textbooks.

The research subjects or respondents were the parties who were sampled in a study. The research subject also discussed the characteristics of the subjects used in the study, including an explanation of the population, samples and sampling techniques 
(random/non-random) used. This researcher choses the eleventh graders of Surabaya, since this grade are taught analytical exposition text as one of a require text that should be learnt by students in the third semester of Bahasa Inggris eleventh grade that legally published by The Ministry of Education and Culture of Indonesia. The researcher followed three steps data finding; reading the English textbooks, identifying texts in each textbook, and selecting the reading texts to be analyzed by using the readability formulas.

Case study research typically includes multiple data collection techniques and data are collected from multiple sources. Data collection techniques include interviews, observations (direct and participant), questionnaires, and relevant documents (Yin, 2014). In case study research, the data collected are usually qualitative (words, meanings, views) but can also be quantitative (descriptive numbers, tables).

The data collection of this current study will be collected through classroom observation. There are two kinds of data collection of this current study, they are:

1. Document Observation

2. Testing

3. Questionnaire

Generally, there are various procedures of collecting data. The main instruments used in the mixed method researches consist of closed-ended, open-ended questionnaires, interviews and classroom observations. These different ways of gathering information can supplement each other and hence boost the validity and dependability of the data. The items of the questionnaires are mainly developed based on the research objectives and research questions, check List.

Discrimination power refers to measurement of the extent of the ability of items of achievement test to distinguish between students' high answers and students' low answers based on criteria. This notion is supported by Arikunto (2006:211), Discrimination power is item's ability to distinguish between students who are good and low capable.

According to research studies, tests have another benefit: they make you learn and remember more than you might have otherwise. Although it may seem that all tests are the same, many different types of tests exist and each has a different purpose and style. First is, diagnostic tests, these tests are used o diagnose how much you know and what 
you know. They can help a teacher know what needs to be reviewed or reinforced in class.

A questionnaire is defined as a research instrument that consists a set of questions or other types of prompts that aims to collect information from a respondent.

Data Analysis is a process of collecting, transforming, cleaning, and modeling data with the goal of discovering the required information. The results so obtained are communicated, suggesting conclusions, and supporting decision-making. Data visualization is at times used to portray the data for the ease of discovering the useful patterns in the data. The terms Data Modeling and Data Analysis mean the same. Data Analysis Process consists of the following phases that are iterative in nature they are data requirements specification, data collection, data processing, data cleaning, data analysis, and communication.

There are a lot of considerations to be taken into account throughout the development. The second reason is that teaching itself is quite time-consuming. So, teachers may do not have enough time to develop new materials (Sheldon, 1988, cited in Sorohiti, 2005). A textbook can often play a crucial role in learners' success or failure (Mukundan, Hajimohammadi, \& Nimehchisalem, 2011).

Analysis of text book result.

The textbook is the main source material used in teaching learning process. It can be great value in teaching, particularly to the beginner teacher. A textbook plays an important role in the teaching and learning process. This is the reason why most English teacher uses a textbook in their class. Textbook are important resources for teaching both productive 4 and receptive skills. It is not surprising that some teacher "use a textbook as the backbone of their courses" (Graves 2000: 174). Many beginner teachers lack the experience and confidence to prepare their own materials and to rely on the textbook to ease their burden.

\section{FINDINGS}

All cycles of reading in whole of English textbook, the teacher found some weakness data that consisted of 115 and 5 unit. Each chapter must be presented in skill of speaking, reading and writing. The next one, for this textbook also take a concern in structure, pronunciation and for vocabulary building. The whole chapter must have 
topic based on the variety of genre of the text such as an analytical exposition text. Then, the result of the assumption of the sentences, words and syllables from each text, is showed in the table 2 below:

Table 1. The description of sentences, words and syllable assumption of calculation in reading text.

\begin{tabular}{|c|c|c|c|c|}
\hline TEXT & & $\begin{array}{l}\text { The number of } \\
\text { the sentences }\end{array}$ & $\begin{array}{l}\text { The numbers of } \\
\text { words }\end{array}$ & $\begin{array}{c}\text { The number of } \\
\text { syllables }\end{array}$ \\
\hline Text 1 & & & & \\
\hline $\begin{array}{l}\text { "Global } \\
\text { Warming" }\end{array}$ & & 39 & 309 & 491 \\
\hline Text 2 & & & & \\
\hline $\begin{array}{l}\text { "Banning } \\
\text { motorbikes } \\
\text { necesssary } \\
\text { housing areas" }\end{array}$ & $\begin{array}{l}\text { of } \\
\text { is } \\
\text { in }\end{array}$ & 63 & 348 & 552 \\
\hline
\end{tabular}

The next table concluded by the result of ASL and ASW assumption of each text which is, it can be seen on table below:

Table 2. The result score of ASL and ASW assumption

\begin{tabular}{llll}
\hline No. & TEXT & $\begin{array}{l}\text { Average } \\
\text { Sentence Length } \\
\text { (ASL) }\end{array}$ & $\begin{array}{l}\text { Average Syllable } \\
\text { per } \\
\text { (ASW). }\end{array}$ \\
\hline 1. & Text 1 & \\
& "Global Warming"
\end{tabular}

\section{DISCUSSION}


The amount data of reading texts then concluded on Flesch Reading Ease formula. The result score of Reading text can be evaluated by formula manually as above and automatically by online counting score on https://readability-score.com/. The researcher always checks the direct result scored by confirmed it then to the qualified guide because of the validity data is very important.

Table 3. The amount score of the reading texts according on Reading Ease Scale of the Flesch Formula

\begin{tabular}{lccc}
\hline TEXT & $\begin{array}{c}\text { READABILITY } \\
\text { LEVEL }\end{array}$ & $\begin{array}{c}\text { DIFFICULT } \\
\text { LEVEL }\end{array}$ & $\begin{array}{c}\text { READING } \\
\text { GRADE }\end{array}$ \\
\hline Text 1 & $\mathbf{5 . 3}$ & Fairly difficult & $10^{\text {th }}$ to $12^{\text {th }}$ grade \\
"Global Warming" & & Fairly difficult & $10^{\text {th }}$ to $12^{\text {th }}$ grade \\
\hline Text 2 & $\mathbf{5 7 . 0}$ & & \\
"Banning of & & \\
$\begin{array}{l}\text { Motorbikes is } \\
\text { Necessary in } \\
\text { housing areas" }\end{array}$ & & & \\
\hline Total & $\mathbf{6 2 . 3}$ & - & \\
\hline & & Difficult & $13^{\text {th }}$ to $16^{\text {th }}$ grade \\
\hline
\end{tabular}

The level of readability reading texts, according on the table above, with similar result with the readability level only for one text. The text has the similar the difficult level. In this case, the analytical exposition text entitled "Global Warming" can be predicted for tenth to twelve students. Another one text "Banning of motorbikes is necessary in housing areas" in the quite difficult level, which is predicted for tenth to twelve students. Those grades belong to Senior High School students except standard, easy, and fairly easy level, in Indonesia. It is stated with Krashen to motivate our students learn harder.

Flesch Reading Ease Formula can be predicted that if the students got readability score of a text is higher than other texts, automatically, it will be easier to be understood by the learners. In fact, if the readability score of a text is lower than other texts, it will make the text difficult to be understood by the students. Textbook is one of input should 
be challenging for the student. It is valuable to give a varieties input. It is also supposed by Krashen in his theory which stated that a handbook or supporting media for learning should be precisely one more step higher than their level. If it reached, this supporting media expected that classroom would full a lot of enthusiasm, active and creative idea for the learners. The result of this research it might the selection of reading input from textbook Krashen mean to give for students. The learners must be actively participated in asking to respond the text in learning process.

\section{CONCLUSION}

Based on the research findings, the researcher concludes this study as follow: the researcher concludes the readability level of reading texts in English Textbook Entitled "Bahasa Inggris" for senior high school students grade XI which readable with Students grade XI are: from five reading texts, there are two texts that readable with Senior High School Grade XI students. It can be classified Flesch Reading Ease Result Score 50 to 60 and 30 to 50 , the description of the style of the text is seems difficult and difficult for style of classification. Most of those texts in English textbook grade XI are $31 \%$ it is categorized fairly difficult.

The English is taught as foreign language that published should to know and the measurement of handbook or study material, be qualified. The research is conduct to analyzed, what kinds of the readability level of English textbook. The readability formula was used because it provided an objective prediction of text difficulty. Reading texts which calculated by Flesch Reading Ease Formula, showed that the level of reading texts entitled "BAHASA INGGRIS SMA/MA/MAK” for grade XI semester 1 published by The Ministry of Education and Culture of Indonesia, was in the Standard level with score of 69.392 . The textbook assumed readable for eleventh students. In short, it concluded that English textbook here was relatively suitable for eleventh grade 
students. Even the "readable" text would be differences that came from the culture, learning habitual, peer-learning, and the source of language itself. In other word, these readability predictions could not be a main reference to choose English textbook for Indonesian students. The readability of Flesch is an alternative prediction, at least it is approved tool which used by many publishers today. There is more readability formula used outside for many subject matters. Dubay (2004:35) suggest other text leveling. This study consisted of renewed cognitive and linguistic that involved a subjective analysis of reading level which examines vocabulary, format, content, length, illustrations, repetition of words, and curriculum. Some opportunity to study how to do next level promptly. At least, the researcher can detect textbooks that toward students' interest and creative support their knowledge by Flesch Reading Ease Formula.

\section{REFERENCES}

https://methods.sagepub.com/Reference//encyc-of-research-design/n333.xml https://universalteacher.com/1/definition-of-research-design/ https://www.slideshare.net/HinaKaynat/checklist-70875784 https://www.tutorialspoint.com/excel_data_analysis/data_analysis_process.htm https://content.wisestep.com/questionnaire-types-advantages-disadvantages/ 